Article

\title{
Learning and Unlearning: Some Reflections on Feminist Praxis and Pedagogic Practice in Religious Studies and Religious Education
}

\author{
Catherine Robinson ${ }^{1}$ and Denise Cush ${ }^{2, *}$ \\ 1 Department of Religious Studies, Bath Spa University, Bath BA2 9BN, UK; c.robinson@bathspa.ac.uk \\ 2 Department of Religion and Education, Bath Spa University, Bath BA2 9BN, UK \\ * Correspondence: d.cush@bathspa.ac.uk; Tel.: +44-1373-474263
}

Received: 27 February 2018; Accepted: 25 March 2018; Published: 27 March 2018

\begin{abstract}
This article evaluates the actual impact and potential implications of feminist pedagogy for Religious Studies in universities and Religious Education in schools. It is based on the authors' experience in the UK, including some international comparisons, with a focus on teaching and learning from a feminist perspective. Applying Grimmitt's threefold model of pedagogy as encompassing aims and content as well as method, this article examines the evidence and extent of change in curricula both in universities and in schools in order to identify where change is required and what that change might be. It demonstrates how feminist pedagogy challenges Religious Studies and Religious Education to rethink their content, methods and aims in a variety of ways, pointing to significant advances and areas yet to be addressed. In so doing, it takes account of diverse feminist voices, other pedagogical priorities and other issues surrounding sex, gender and sexuality that challenge the category of the feminine and the appropriateness of a gendered analysis.
\end{abstract}

Keywords: feminisms; study of religions; religious studies; religious education; gender; sexuality; feminist epistemologies; intersectionality

\section{Introduction}

Feminist pedagogy is centrally concerned with learning-what is taught, how it is taught and why it is taught. By the same token, it is also concerned with unlearning in that it challenges the conventional curriculum, traditional classroom practice and narrow notions of the purpose of education. Yet what is feminist pedagogy and what has it meant (indeed, what might it mean) for Religious Studies and Religious Education? In order to answer these questions, it is first necessary to offer some working definitions and introductory discussions of key terms.

\section{Working Definitions and Introductory Discussion of Key Terms}

\subsection{Feminism}

Feminism is a protean phenomenon, encompassing a broad range of outlook and opinion. There are different types of feminism as ideology, also different waves of feminism historically and even different geo-political locations for feminism. Under these circumstances, it is perhaps preferable to think in terms of feminisms rather than feminism but there has been considerable reluctance to use the term feminism at all since feminism has been regarded as both produced by, and promotive of, the interest of white middle-class western women and hence as complicit in the oppression of other women, leading to other terms and approaches such as 'Womanism' and 'Mujerista' that also feature in what has generally been labelled feminist scholarship on religion (Martin 2001, p. 539; 
Isasi-Diaz 2001, p. 498). Mirroring this debate about one or many feminisms is the debate centring on the category of woman upon which feminism in whatever form or forms would seem to depend. Just as sex and gender are understood in a variety of ways, privileging the biological or the social, with obvious implications for the category of woman (Mathieu 1996), there has been an increasing tendency to abandon 'a unitary and essentialist female nature' in favour of 'a new stress on differences' whereby "“[w]oman" has been replaced by the multitudes of women' (Peskowitz et al. 2001, p. 394). This poses a problem in that if proper account is taken of plurality and thus gender deemed to be a social construction, there is no basis for activism of a feminist kind (Kishimoto and Mwangi 2009, p. 89). There is a paradox here, then, that the very attempt to acknowledge diversity in order to prevent the marginalisation of specific (groups of) women means those very same (groups of) women might be deprived of the cohesion necessary to political action, leading some to advocate a 'strategic essentialism' (Kishimoto and Mwangi 2009, p. 90). Crucially, as feminist scholars have shown, religions play a major part in interpreting gender while frequently explaining its origins along biological lines.

\subsection{Pedagogy}

Pedagogy is sometimes used simply as a synonym for teaching, or teaching strategies and methods, or for particular theories of teaching and learning. Robin Alexander defines it as the act of teaching and its attendant discourse' (cited in Husbands and Pearce 2012, p. 5). Grimmitt (2010, p. 302) points out that both the term 'pedagogy' and actually paying attention to underpinning theories of learning and teaching have been relatively neglected in England compared to continental Europe and the USA, however, since the publication of his book in 2000, the term at least has become popular in Religious Education circles. We propose to use Grimmitt's working definition of pedagogy as 'a theory of teaching and learning encompassing aims, curriculum content and methodology' (Grimmitt 2000, p. 16), not just the how, but also the what and why.

\subsection{Feminist Pedagogy}

Feminist pedagogy is defined by Crabtree and Sapp (2003, p. 131) 'as a set of classroom practices, teaching strategies, approaches to content, and relationships grounded in critical pedagogical and feminist theory'. Influences commonly cited include Paulo Freire's progressive approach to education entailing 'a critique and a refusal of the "banking system" of education' in which he rejects as oppressive the widely-shared view that that the task of the teacher is to transfer knowledge to her/his pupils as if they are empty vessels waiting to be filled (Freire 1998, p. 32). Hence bell hooks, an advocate of feminist pedagogy, acknowledges Freire's sexism while insisting that his ideas have contributed to her own thinking in which she refers to Freire's insight 'that education can only be liberatory when everyone claims knowledge as a field in which we all labor' (Hooks 1994, pp. 14, 49, 52).

Among the characteristics attributed to or associated with feminist pedagogy are the following: philosophical perspectives critiquing the Enlightenment model of knowledge; integration of experience as a resource; an emphasis upon praxis as the expression of an engaged ethic; creation of an egalitarian and collaborative community; empowerment of students as individuals; recognition of the transformative potential of learning. However, it is noteworthy that feminist pedagogy rarely acknowledges religion as a significant factor even insofar as it does acknowledge other variables such as ethnicity, age, class, disability, sexuality, etc. Moreover, given that religions have a complex and contested relationship with feminism, and that different academic disciplines pose greater challenges where the subject matter has feminist implications (Crabtree and Sapp 2003, p. 138), it is vital to consider how feminist pedagogy can inform Religious Studies and Religious Education.

\subsection{Religion}

Religion is another contested concept and, as in the case of feminism in relation to women, contrasting positions are adopted that reflect essentialist and constructivist positions as to whether religion is a universal feature of human society or a product of the modern West of questionable 
application to non-Western cultures, a real object or a scholarly reification (Smith 1978, pp. 51-53; 1982, p. xi; Staal 1989, p. 393). An area that has proven particularly contentious is the treatment of religion as having an independent and irreducible existence which some feminists have attacked on the grounds that treating religion as an autonomous and abstract entity effectively excludes a feminist analysis of the complicity of religion with negative impacts upon women. This is very much Rosalind Shaw's point when she stresses that '[t]he sui generis concept ... stands in a contradictory relationship to the premises of feminist scholarship' by divorcing religion from its social and cultural context and thus treating as irrelevant the problem of women's unequal access to power (Shaw 1995, p. 70). Thus feminist scholars in Religious Studies tend to the constructivist understanding of 'religion' and employ it as a category which may be a useful tool for analysis in some contexts but unhelpful in others.

\subsection{Religious Studies}

Religious Studies, though much contested (see, for example, Wiebe 2005), is generally understood in the UK as a multidisciplinary, non-confessional study of a range of religions and, sometimes, worldviews that play an equivalent role in human lives as those labelled 'religious'. In summary, '[t]he content is determinedly plural', involving 'a study rather than endorsement or refutation of the claims of religions' and 'prioritising neither textual and historical, nor philosophical or theological, nor social scientific approaches' (Cush and Robinson 2016, p. 27). Hence the constitution of the British Association for the Study of Religions (affiliated to the International Association for the History of Religions) as 'the historical, social, theoretical, critical and comparative study of religion/s', stressing that the organisation 'is not a forum for confessional, apologetic, or similar concerns' (BASR n.d.). The emergence of the subject in the UK was marked by the University of Manchester's introduction of Comparative Religion in 1904 and the foundation of the Religious Studies Department at the University of Lancaster in 1967 (Russell 2011, p. 2).

In broader terms, Religious Studies developed in the modern era in the context of the intellectual heritage of the Enlightenment, featuring factors such as the Western interest in 'other' religions, that is, religions other than Christianity, and encompassed various methodologies including the sociological and anthropological rather than the dominant theological paradigm (Jakelic and Starling 2006, pp. 194-95). The European Enlightenment with its emphasis on the rational and the empirical, its belief in progress and its enthusiasm for the new, gave birth to many modern academic subjects, including the study of religion. While the Enlightenment saw religion as a private personal matter of faith, a realm of meaning and values divorced from the realm of knowledge and facts, often as a matter of emotion, intuition or even 'taste' on a par with musical or artistic sensibility, it proposed that religion could be studied on the model of the natural sciences, that is, rationally and empirically, hence the term 'science of religion' with its positivist overtones, thereby articulating and applying Enlightenment ideals. Clearly, scholars are not necessarily divorced from, or even alert to, their assumptions and prejudices when these are the norms and values of their societies and, in this connection, Warne observes that 'the prescriptive gender ideology of separate spheres ... was naturalized, ontologized, and authorized in the scientific study of religion from its origins' (Warne 2000, p. 150). Accordingly, an aspect of the intellectual heritage of Religious Studies has been its uncritical acceptance of a gender ideology that was in fact as ethnocentric (and class-biased) as it was androcentric (Warne 2000, p. 149).

\subsection{Education}

Education is another highly contested area, debated by politicians and the general public as well as by academics. Even its derivation is disputed-whether from educere which suggests drawing out an innate potential or educare suggesting leading or training by another. Schreiner (2017, p. 38) draws upon the work of Gert Biesta to identify three domains of education- 'qualification', 'socialisation' and 'subjectification' - and argues that education has been distorted in recent times by an emphasis on qualification for the global labour market and that 'an economic orientation of education means that 
economic growth and competitiveness become the dominant drivers of education, while other goals become subordinated'. A feminist approach would seek to restore the balance between Biesta's three domains. 'Qualification' (knowledge, skills, attitudes) and gaining employment are not unimportant, and indeed may be crucial in empowering under-represented groups such as women. 'Socialisation' in the sense of initiation into culture and social solidarity, 'learning how to become part of existing traditions and ways of being and doing' (Biesta 2013, p. 4), where approached critically, is relevant to the feminist agenda of establishing egalitarian community. However, most crucial from a feminist perspective is 'subjectification', the freedom to develop one's own identity in relation to existing traditions, to critique those traditions, and to work to improve them. Biesta (2017) stresses that this freedom is not license to do whatever one desires, but continually asking oneself whether what one does is best for others and the planet as well as oneself. Certainly feminists would want to question the marketisation of education and the reduction of human beings to human resources.

Religious traditions too have diverse perspectives on education, as they have views on the nature of human being, valid sources of knowledge, and visions of a good society. It may be that literacy is seen as important in order to read sacred texts. Negatively, in the past and even sometimes today, access to formal education may have been limited by gender, or class, or race, in part through the influence of religious teachings. More positively, if a sweeping generalisation, most religious traditions have seen education as something that contributes to human flourishing rather than the acquisition of qualifications for the job market, concerned with wisdom rather than just knowledge.

\subsection{Religious Education}

Religious Education is a field of great controversy. Even the name is ambiguous, in that it suggests to many that the endeavour is itself 'religious', with an aim of developing religious faith, whereas to others it is an academic school subject like any other, with educational rather than religious aims. Internationally, some countries leave the subject out of their state-funded secular education systems altogether because it is seen as 'religious'; others include confessional or denominational Religious Education in the religion or religions/worldviews deemed to be an intrinsic part of being a citizen of that state; and still others include a non-confessional, multi-faith subject as an important part of preparation for life in a world of diverse religions and worldviews. The UK and Sweden pioneered this last approach from 1969, and a few other countries have since followed on such as Norway and South Africa. Although there are also state-funded religious schools in the UK, for many decades the understanding of Religious Education, in fully state-funded schools at least, has been one of educational aims and multi-faith content. This type of Religious Education is suitable for students from all faiths and none, taught together. Hence it is called 'integrative' Religious Education by Alberts (2007) and 'Religion Education' in South Africa. In the UK there is currently a debate about whether the subject needs a new name to avoid the aforementioned confusion with confessional religious education (Commission on Religious Education 2017, p. 64).

\section{The Authors' Autobiographies}

This chapter is a development of ideas first explored in Cush and Robinson (2014) on the relationship between Religious Studies and Religious Education featuring feminism as one of the themes. In writing this paper, we are drawing upon many of the sources that have informed our own thinking and practice over the last thirty or forty years, indeed, some of which have become course readers for students, including intending teachers. More than this, of course, it reflects deep personal engagement with a feminist project as researchers and as teachers in the UK. Since a fundamental premise of feminist pedagogy is that our own experience and biography shapes our current understanding, we begin with ourselves. 


\subsection{Professor Denise Cush Autobiography}

I have always been a feminist in the sense that my parents, especially my mother, considered that girls were as good as boys, but have only really engaged with feminist theory since working with Catherine. I am particularly grateful to have discovered that women's experience can be a legitimate source of authority as this validated how I have always instinctively proceeded, in a world where my experience so often ran counter to what was asserted by the powers that be. From an upper working class background, I have tried both to succeed in the academic world created by patriarchy, whilst simultaneously critiquing its values. So I consider it progress that whereas my great, great grandmother could not even sign her name, my grandmother left school at 13, and my mother at 16, I was able to study at Oxford University (St. Hilda's College) and Lancaster University and later become the first female professor of Religious Education in England in 2003. Oxford Theology in the early 1970s (when colleges were still divided by gender, and women could not be ordained as priests in the Church of England) was a very male preserve, and Lancaster, though progressive in many ways, was still studying 'the religious experience of mankind'. I deliberately resisted specialising in women in religion just because I was a woman, fearing that it might be a kind of ghetto. Reflecting on my publications in preparation for my somewhat delayed PhD in Religious Education in 2012, I wondered what the connection was between the various topics in which I have taken an interest: pluralism; the rationale for Religious Education; Religious Education policy and the debate about faith-based school; pedagogy and methodology in Religious Education and Religious Studies; the relationship between Theology, Religious Studies and Religious Education; Buddhism, Hinduism, Humanism and secular worldviews, Jainism, Christianity, contemporary Paganism and 'alternative spiritualities'. I realised that these topics were linked by a fundamental commitment to equality and diversity, championing whoever was being left out, whether that was women and girls, a religious tradition neglected in programmes of study, or the subjects of Religious Studies at universities and Religious Education in schools being under-valued. In my subsequent career I have experienced a number of incidents that indicate that, although women have made great progress, there is still a long way to go. In spite of my relative success in the elite system of education, I have always attempted to teach in the spirit of feminist pedagogy, with an emphasis on relationships, establishing an egalitarian community of enquiry and empowering students as individuals.

\subsection{Dr Catherine Robinson Autobiography}

I had originally intended to write my PhD on Hindu reformers and revivalists and their efforts on behalf of women but my plans changed as I became aware of the vital contribution made by women themselves and hence concentrated on the Indian women's movement. I dedicated the resulting monograph to my maternal grandmother whose outlook was shaped by 'first wave' feminism. From a very similar background to Denise, my own university experience was different as my first degree was in Religious Studies at the University of Stirling. Even so, for the most part, feminism was not accommodated or even acknowledged. As a new lecturer, working with Denise, I expressed an interest in introducing a module on religion and gender and, though the content has changed to reflect emerging areas related to the recognition that men are gendered beings and also issues of sexuality as well as developments such as Queer and Trans, the dilemma remains the same. While such a module provides the opportunity for dedicated coverage of such themes and ensures that they are not omitted from the programme, it can mean that other modules need not address these themes at all and mean it is possible for students to avoid them simply by not taking the module in other question. Yet, even where gender is included, there is still a marked tendency to devote a session to 'Women in ... .' which suggests, often rightly, that the rest of the module has nothing whatsoever to do with women and, even where women's role whether as participants or non-participants merits mention, this is not on the agenda. Consequently, I have tried to formulate a new approach in a module on Hinduism based on the purusharthas (legitimate ends of life) where gender permeates the module. Involved in this, I have attempted to integrate aspects of feminist methodology in terms of introducing autobiography as an 
invitation for students to reflect on my outlook and approach, and take this into account in formulating their own responses to material presented. This relates to an aspiration that students should not only gain academic knowledge and understanding but also be afforded opportunities to broaden their horizons and pursue their own interests in a setting that I hoped would be both intellectually rigorous and personally supportive.

\section{Content, Methods and Aims}

Our now retired Head of School, Fiona Montgomery, writing with her colleague Christine Collette about the discipline of Women's Studies while looking towards the new millennium, commented on the 'lack of focus on actual practice' (Montgomery and Collette 1997, p. 1). Arguably, the same applies to Religious Studies and Religious Education. In what follows we use Grimmitt's threefold model of pedagogy —aims, methods and content, albeit ordered differently — to examine the feminist credentials of Religious Studies at University and Religious Education at school level and make suggestions as to how taking feminist pedagogy seriously might make a difference. Some shared issues and debates are outlined first at the level of research on religions and public policy on education before investigating the implications for Religious Studies and Religious Education in the classroom. The distinctions between aims, methods and contents that structure the discussion are at best helpful for the purposes of analysis as in reality they are inseparable as interdependent and interrelated aspects of the pedagogical process.

\subsection{Content in Religious Studies and Religious Education}

Feminist pedagogy is predicated upon an alternative epistemology that replaces the objective and abstract view of knowledge with the subjective and embodied whereby knowledge becomes associated with liberatory values and lived experience (Crabtree and Sapp 2003, p. 132; Madoc-Jones 1997, pp. 13-14). Consistent with this, experience is deemed a form of knowledge and a source of authority that informs a different sort of theorising that is grounded in real life (Madoc-Jones 1997, p. 15; Kishimoto and Mwangi 2009, p. 87).

Clearly, this requires changes to the curriculum and, in broad terms, feminism has led scholars to identify weaknesses in the content of Religious Studies courses, especially but by no means exclusively in the past. Feminism has demonstrated that earlier scholarship uncritically accepted men's religiosity as normative, either omitting women entirely or marginalising them, thereby achieving neither accuracy nor comprehensiveness since it could not differentiate between women's and men's gender roles in religions and it could not include areas of religious life which are the sole province and preserve of women. As Kinsley observes, history of religions has in fact been centred on men and, insofar as women have featured in some subsidiary capacity, they did so from the perspective of men and in relation to men (Kinsley 2002, p. 3). Feminism has also exposed a pervasive male bias predicated upon unexamined presuppositions equating the masculine with the human and ignoring the importance of gender. In this connection, Stenger's account of the philosophy of religion highlights the falsely universalised and decontextualised notion of the human subject that erases its gendered nature (Stenger 2002, p. 148).

Therefore, feminism has recognised the imperative to undertake a critical reinterpretation of the existing body of knowledge, its sources and resources, also entailing the introduction of new areas of enquiry altogether. For instance, Jonte-Pace's analysis of Sigmund Freud's theory of religion reveals the normative status of men in his work, the lack of agency attributed to women and the superiority of men in ethical and consequently also cultural and religious terms (Jonte-Pace 2002, pp. 102-4). Feminism also advocates focus on the specific situations-social, political and economic, historical and contemporary, etc.- - in which religions are found. As Jones has pointed out, this entails acknowledging the part played by gender in demarcating this specificity and selecting approaches that are attentive to meaning (Jones 2002, pp. 78, 82).

Feminism has indicated that different topics merit study, concentrating on women in their own right and seeking to offer a fairer and fuller account of women's religious lives in order to achieve 
a holistic and nuanced picture. Associated with this is a stress upon ordinary women to avoid accusations of tokenism as well as a stress upon those aspects of religiosity in which women feature prominently. These aspects include women's rites that, as Bell reports in relation to Aboriginal religion, were not previously understood to be significant due to the difficulties of fieldwork in sex-segregated settings, the association of women with the profane on the part of anthropologists of religion and their tendency to accept that men could give an account of the religion as a whole (Bell 2001, pp. 255-56). These rites are not only found in indigenous traditions and research on girls' initiation rites among Catholic women in Zambia has demonstrated women's determination to retain control and avoid the rites being appropriated by the male church hierarchy, also illustrating how being disregarded as a young, unmarried and childless woman in some ways actually aided the researcher (Rasing 1995). Another aspect of woman-centred religiosity highlighted more recently is the rise of contemporary Goddess spirituality where thealogy refers to a feminist rejection of, and response to, the patriarchy of mainstream religions and reflection on the sacred and the divine in relation to women and the Goddess (Reid-Bowen 2005, p. 191).

These topics necessitate a move away from a scholarship centred on religious authorities and occupants of leadership positions in a formalised institutionalised hierarchy, such as a hierarchy relegating other members of religious traditions-among them the vast majority of women-to a subsidiary supportive position and hence to invisibility. The conventional style of scholarship is seen to create the situation in which women are judged to be peripheral, since it formulated criteria for assessing participation in religion in terms of roles generally restricted to men. Instead, it is recommended that other sorts of contributions are considered, and when this is done, a rather different picture emerges. This is evident when the financial patronage of Indian religious institutions by women is examined. Orr refutes the way in which such patronage is disparaged as part of a lesser path for the less spiritually advanced, pronouncing that 'marginality depends on how the territory is defined' and proposing 'another type of map that represents religious life as it has existed in real time and space', reaching the conclusion that such a map which features financial patronage reveals women's actual importance (Orr 2000, pp. 134, 137). There are some examples of women succeeding in discharging roles and responsibilities usually limited to men such as the seventh century Christian St. Hilda of Whitby, founding abbess of a double monastery (both nuns and monks), who taught theology, Latin and literature to male clerics including several who went on to become bishops, as well as advising rulers and 'common people' (Farmer 1988, pp. 206-7). Even so, such examples are rarely highlighted.

Reorganising the curriculum content involves a sustained effort to rediscover and revalue women's experiences, their testimony and witness, and simultaneously to expose misogyny and oppressive norms and stereotypes. It is not just a matter of adding a lecture or module on women or a chapter on women to existing curricula or textbooks (though that is a start) but rethinking the nature of knowledge, the concept of 'objective fact' and including a feminist perspective on all topics such as texts, sources of authority, religious experience, ritual practice, stories and myths, art, music, dance, ethics, the role of religion in political, public, social and cultural life, and in identity formation, whether in systematic studies of one tradition or comparative thematic study. In addition, the ability to undertake such a reorganisation of the curriculum is constrained by a number of factors such as institutional priorities, different interests within a staff team and different attitudes among students. Nevertheless, we have both seen considerable, if not consistent, change across the sector over the course of our careers that means, unlike us as undergraduates, students today should at least have some opportunity to explore gender and feminism in their Religious Studies programmes.

When Denise started teaching in the 1970s, accounts of religions in the school curriculum and materials were still taking men's experience as normative in an unreflective way. Phrases such as 'other men's faiths' were used without anyone noticing. Descriptions of religious traditions reflected the way religions mostly were-male founders, scriptures mostly compiled by men, current leaders and spokespersons were men, ritual practitioners were mostly men (the Church of England did not have women priests until 1994). The philosophers and scientists mentioned were also all men. It was 
not that women and girls were deliberately omitted (there is the odd picture of a woman in a burga, for instance, in resources from that time) they just did not feature as any of the important actors in the important stories. Sometimes teachers and pupils would notice and make a critical comment, and hope that things would improve in the future.

Things have, indeed, improved more recently. King (1990, p. 280) identified the late 1980s as the turning point for gender in both Religious Studies and Religious Education, with the Shap Working Party on World Religions in Education publishing 'Women in Religion' in 1988 and the formation of WIRE ('Women in Religious Education'), a pressure group of which Denise was a member, which did not last very long into the 1990s, but made its point and then members moved on. Very gradually such initiatives have had an impact as an examination of national statements about Religious Education, examination specifications and textbooks will show. The 2013 guidance from the Religious Education Council expects students aged 13-16 to 'consider why so many sources of wisdom and authority in religions and worldviews are men, and so few are women. They appraise some sources of female wisdom, from within or beyond religions and worldviews' (REC 2013, p. 25). The Swedish national curriculum is more thoroughgoing, as the examples collected in Cush (2016, p. 156) illustrate. Comparing examination specifications is enlightening. Comparing the syllabuses for Advanced Level Buddhism (for students aged 16 to 18 years) when Denise was teaching it in the 1970s and 80s with the latest 2016 specifications, much is still the same except that a section on 'Women in Buddhism' has been added (the main other new section being 'Engaged Buddhism'). Progress has been made, but adding a section or chapter on women insufficiently challenges the rest of the way in which the tradition is presented. Women are still exceptionalised and, as there is never a section on men in Buddhism, men's experience remains normative. Visual images are very powerful and, although some publishers have made an effort to embrace diversity in their illustrations, a comparison of a 2005 textbook written by a woman and a 2017 textbook written by a man show that things can easily go backwards, the former having pictures of female and lay Buddhists from various sub-traditions, but the latter illustrating almost every page with a man in an orange robe. The recent popularity of papers on the philosophy of religion have also set things back, as almost all the philosophers studied are men, and the gender-critical turn in Philosophy is much more recent even than in Religious Studies.

\subsection{Methods in Religious Studies and Religious Education}

Feminist pedagogy involves praxis, that is, an ethical commitment to change, fostering an awareness of discriminatory and exploitative structures and systems in order to facilitate their removal (Crabtree and Sapp 2003, pp. 131-32; Kishimoto and Mwangi 2009, p. 98). In turn, this leads to different relationships between teachers and students, and between students, in which a learning community is formed on the basis of equality and collaboration rather than hierarchy and competition (Kishimoto and Mwangi 2009, p. 87; Welch 1997, p. 40).

One influential way of researching religions has been phenomenology that has served both as a specific theory and method and as a general philosophy for the subject, uniting diverse approaches within an overarching framework valuing the believer's views in an open and inclusive manner. It involves empathy (imaginative identification with the believer), eidetic vision (intuition of the essence of a phenomenon) and epochê (suspension of judgement in order to understand a phenomenon). Irrespective of whether a case can be made that phenomenology of religion can accommodate gender-critical perspectives, it can hardly be doubted even by its staunchest defenders that it has failed to do so in the past. If women have been regarded as 'Other,' this is surely a failure in empathy; if gendered inequalities in power and status have been ignored, this is surely a negative consequence of the eidetic vision; and if the 'bracketing out' of belief and bias requires that gender is ignored in the pursuit of impartiality, this is surely a neutrality achieved at the expense of the inclusion of women. Notwithstanding, Young would disagree with such a critical evaluation, refuting frequent feminist rejection of the phenomenological insistence upon essence and objectivity, and also makes the observation that the development of phenomenology predates 
contemporary gender-sensitivity (Young 2002, pp. 31-36). Certainly, phenomenology is by no means the only discipline in a multidisciplinary subject area that has poor feminist credentials.

Generally, feminism has prompted a recognition that the information base has to be broadened to take proper account of women but, to a greater or lesser extent, has also involved some changes in theory, methodology and interpretive paradigms. This includes an acceptance of the ethical dimensions of study rather than regarding Religious Studies as a disinterested intellectual activity without any real-world responsibilities. Gross not only subjects the notion of objectivity to scrutiny, stressing that objectivity frequently means merely conforming with received opinion, but also comments upon the tendency of scholars to stress being 'value-free' (Gross 1996, pp. 12-13). In contrast, she insists that this is impossible due to the subject's engagement with religions, adding that '[o]ne should feel that sexist, racist, ethnocentric, and religious chauvinisms, if present, are being threatened by the academic study of religion' (Gross 1996, p. 13). It is her belief, then, that the study of religions involves a strong ethical dimension. Moreover, feminism does not deem it plausible that a researcher's conduct of research remain unaffected by the researcher's own beliefs and values. Since every researcher sees from a personal perspective, from a standpoint, what is essential is reflexivity whereby the researcher is conscious of what is brought to the study beyond academic expertise and interest. This is listed in Knott's 'guidelines for research practice' where she itemises '[a]n awareness of one's own feelings and thoughts throughout and a consideration of their role in the research as a whole' (Knott 1995, pp. 209-10).

Certainly, feminism has suggested a new way of studying religions. Building upon her declaration that '[1]ess than half the story has been told', Carr advocates asking a series of questions about women intended to determine the reality of women's presence such as '[w] hat was/is happening to women, what were/are women doing and thinking, what was/is the relative status of women and men with regard to symbolization, valuation, creativity, participation, opportunity, power, institutional and informal support and constraint?' (Carr 1990, pp. 93-94). This could be seen as exemplifying the hermeneutics of suspicion adopted and applied by so many feminists in relation to sacred literature and religious tradition as well as pre- and non-feminist scholarship. This is what $\mathrm{O}^{\prime}$ Connor calls a 'gender-sensitive hermeneutic' (O'Connor 1995, p. 46) and denotes a critical response that she elsewhere expressed as 'the three Rs of rereading, reconceiving, and reconstructing traditions', a project that includes a focus upon women in reviewing sources, identifying material that testifies to what has been forgotten or erased from the record and the formulation of new accounts informed by new data and modes of study (O'Connor 1989, pp. 102-4).

This approach lends itself to students' active participation in class and to a different relationship between lecturers and students. In fact, the stress on the relationship between students and tutor is crucial to feminist teaching methods. Notwithstanding that the relationship is asymmetrical in that the tutor is generally further advanced on the academic path and thus qualified to assist students in their learning and, more problematically, is required to assess and grade students, the relationship is one between equal human beings. Thus lectures and seminars become a joint exploration, where tutor expertise meets student experience. We have always tried to take the fear out of learning and empower students by giving them confidence in their abilities. Having both worked at a university with an active Widening Participation Office that seeks to support people from groups under-represented in Higher Education (including those from families with no previous history of participation at tertiary level in addition to those from lower income backgrounds and less advantaged areas), these are particularly important. Accordingly, we hope to convey our own enthusiasm and fascination in our teaching and promote students' enjoyment of our classes. Nevertheless, there is a danger that stressing good relationships with students can lead to (mainly) female staff becoming identified with pastoral (quasi-maternal) roles leaving male staff to pursue roles deemed more prestigious such as research and management.

As well as valuing student experience as a resource, we have always stressed experiential learning and insist that all our Religious Studies students engage in mini-fieldwork projects where 
they spend time staying with religious communities, meeting 'real' religion rather than textbook versions. This stress on lived experience is characteristic of feminist pedagogy, and often means that more women are encountered than would be true in religions studied, for example, through their sacred texts.

Unlike in Religious Studies, a number of clearly defined and differentiated pedagogies in Religious Education can be identified, both in the sense of theoretical frameworks and practical methods. A number of influential ones are outlined in Grimmitt (2000). Some are more in line with feminist pedagogy than others such as Grimmitt's own constructivist pedagogy, where students are involved in creating knowledge, interpretivist and dialogical pedagogies which stress engaging with real people, and reflexivity about one's own position, and experiential pedagogies which centre on the students themselves, and include exercises resembling forms of meditation. When it comes to the study methods employed by pupils, there has been a welcome emphasis on student enquiry, and especially 'a community of enquiry' approach (Baumfield 2002, p. 95) where students work collaboratively. A recent resource for primary aged pupils (5-11) introduces young children to some of the methodologies for studying religions used by adult researchers through four characters: Ava who uses interviews, Derek who asks philosophical questions, Hugo who uses participant observation and Suzie who looks at stories through texts and creative arts (Freathy et al. 2015). Thus children are introduced at an early stage to the creation of knowledge and how different methods and perspectives affect the results. At least there are two female and two male 'RE-searchers', even if it is a little disappointing that yet again the philosopher is male. Although it is debated, many in the UK 'Religious Education Community' stress that the subject is not only about gaining knowledge about religions, but also for pupils to develop and be enabled to express 'their personal reflections and critical responses to questions and teachings about identity, diversity, meaning and value, including ethical issues' (REC 2013, p. 14). Phenomenology, much misunderstood in Religious Education circles as merely descriptive, interested only in observable features such as rituals and buildings, and uninterested in questions of truth, is now currently out of fashion but has left an enduring and important legacy in approaching religious and non-religious worldviews with fairness, empathy and respect, employing critical evaluation after rather than before gaining knowledge and understanding. On the whole, though not gender-critical in a sophisticated sense, methods of teaching and learning in Religious Education are at least potentially in alignment with feminist pedagogy.

\subsection{Aims in Religious Studies and Religious Education}

Feminist pedagogy is inspired by the imperative to empower students and promote their full participation as individuals (Crabtree and Sapp 2003, p. 132; Kishimoto and Mwangi 2009, p. 87). This means that the purpose of education goes beyond the intellect to encompass the personal in the fullest sense as a transformative activity (Kishimoto and Mwangi 2009, p. 98; Shah 1997, p. 103).

Much is implicit in what has gone before. However, in Higher Education it seems as if the language of aims has been superseded by learning outcomes with general confusion between aims and objectives and also between course and subject aims. Consequently, this area is frequently neglected with little attention paid to why one should study religion and, where addressed, in all probability, disputed.

A leaflet produced by TRS-UK, the organisation representing both Theology and Religious Studies at UK universities, combines what might be called an instrumentalised view of education that stresses the value of a degree in terms of skills for employment with the prospect of being able to bring about change for the better (TRS-UK 2013). If the leaflet is correct to observe ' $t$ the world urgently needs people who are good at thinking about religion' (TRS-UK 2013), then should this in turn involve a gender-critical approach to religion?

The additional complication is the sometimes fraught relationship with Theology from which Religious Studies has struggled to distance itself, entailing scholars' efforts 'to vocalise their differences and assiduously police the boundary with theology' (Knott 2017, p. 6). A case can be made that 
Theology's greater prestige and institutional links may have made it a less welcoming environment for feminism than Religious Studies with its counter-cultural associations and high proportion of women. Yet Theology as a (methodologically) insider discourse, in the sense of accepting the premises of a given religion as the foundation of enquiry, has not merely accommodated but integrated personal and political commitment whereas the conventional positioning of the scholar in Religious Studies as an objective observer has led to some suspicion and concern about anything that smacks of an engaged outlook, even if one of the insights of feminist scholarship has been to problematise the notion of such objectivity. Hence Feminist Theology, though not without its own hard-fought battles with a frequently hostile establishment, arguably requires a less radical revision at least at the level of motivation and aspiration than Religious Studies.

Degrees in UK universities are required to meet academic standards as specified in Subject Benchmark statements. The Subject Benchmark Statement Theology and Religious Studies as the title suggests does not draw a clear distinction between Theology and Religious Studies. In the introduction, it makes explicit mention of the gendering of religion, highlighting feminism as a feature of many programmes, subsequently identifying gender as one of the issues investigated and gender studies as a related subject (Quality Assurance Agency for Higher Education 2014, pp. 6, 10-12). There is no section devoted to the aims of the subject but there is a sub-heading on ' $t$ ] he social value and wider impact of theology and religious studies' that makes claims for Theology and Religious Studies that go beyond what might be expected from the study of other subjects (Quality Assurance Agency for Higher Education 2014, p. 8). In this context, it is contended that that there is potentially 'a profound impact on the student's life and outlook', promoting personal development and, for example, conducing towards self-respect and self-awareness alongside a positive response to encounter with diversity (Quality Assurance Agency for Higher Education 2014, p. 8).

Yet what is the scope or reach of any empowerment or transformation? It is surely ambitious to seek to change Religious Studies though without that ambition what has been achieved to date would not have been possible. However, at the very least, King regards a greater awareness of gender as a human institution as significant for Religious Studies but also for religions since gender norms are inextricably bound up with religious belief and practice (King 2002, p. 375). She concludes her article on the future of the subject in the light of challenges including feminism with an inspiring vision when she declares 'I believe passionately that religious studies can fire people's minds and hearts; it can help them to know and understand, to analyse and explain, but also to love, to grow strong and confident, and to care and be compassionate' (King 2002, p. 385). On this basis, Religious Studies can serve to reveal the pernicious impact of patriarchy and thereby promote a new awareness that can prompt change.

An area in which such change is understood to be imperative is the environment, another aspect of King's holistic approach that brings together her interest in spirituality, ecology and gender (King 2010). Certainly, an ever more important dimension of contemporary feminism is ecofeminism which has been deemed to be 'feminism taken to its logical conclusion, because it theorizes the interrelations among self, societies, and nature' (Birkeland 1993, pp. 17-18). In this connection, ecofeminism supplies the analytical resources to reveal the root causes of the ecological crisis where damaging anthropocentric attitudes are traced to an underlying androcentrism (Gaard 1993, p. 6). This facilitates a recognition of the complicity of many religious norms and values in the degradation of the environment, and also a critical reappropriation of positive religious notions of the interrelatedness of life and the location of the self in a living cosmos consistent with feminist ideas. Clearly, this chimes in with a common sense of urgency about the need for change. Thus a corollary of threading feminist concerns through the content, methods and aims of religious studies at university and religious education in schools is that there will also be a continual recognition of the embodied context and the interrelationship with other living beings and the planet itself in which these activities take place.

There is much more academic discussion about aims and purposes in Religious Education than in Religious Studies. Research (such as Conroy et al. 2013) and inspection (for example, 
Ofsted 2013) have also suggested that there is much confusion among teachers about aims and purposes. The disagreements are, on the whole, about three main issues. First, whether Religious Education is in any sense 'confessional'. Is it a secular academic subject or does it contribute to faith formation? This debate tends to occur mainly with reference to the state-funded schools 'with a religious character', a designation applying to one third of primary schools (pupils aged 5-11) and one sixth of secondary schools (pupils aged 11-18) in the UK. Second, within non-confessional, multi-faith Religious Education in fully state funded schools, there is a tension between those who stress academic knowledge 'about' religions and associated learning skills, and those who consider that the priority is to help pupils to develop their own beliefs, values and identity. The third main discussion (notably in Conroy et al. (2013, pp. 43-44)) is whether the subject has been distorted by concerns outside its main aims-expected to deliver on moral education, sex and relationships education, 'Community Cohesion', 'British Values', Spiritual, Moral, Social and Cultural Development, Citizenship, philosophical understanding, virtuous dispositions, understanding artistic and literary heritage-and all from a subject that often receives less time, resources and specialist teachers than any other.

However, some generalisations can be made. UK Religious Education aims to help pupils know about and understand a range of religions (and sometimes other worldviews), appreciate their impact on individuals and societies, gain wisdom from their studies, reflect on their own beliefs, values and identities, acquire the skills and vocabulary to discuss matters related to religions in an informed and intelligent way and thereby live respectfully with individuals and communities whose belief, values and customs differ from their own (see, for example, REC 2013). So, as with methods, there is potential for emphasising aims that validate the pupils' experience, question the Enlightenment view of knowledge, and seek to transform individuals and society. However, this is difficult in an education system increasingly geared to market forces, focused on outcomes, grades and qualifications, which judges both pupils and schools on examination results, entrance to prestigious universities and eventual salaries. In the current climate in the UK, Religious Education is neglected as unimportant by pupils, schools and parents as it is not seen as relevant to earning potential for the individual and the nation (for a summary of the challenges facing Religious Education in England today see (Commission on Religious Education 2017, pp. 39-50)). A feminist approach to the question of aims might perhaps be to empower pupils by enabling them to succeed in the current system that stresses knowledge, skills, grades and qualifications while simultaneously maintaining a critique which places more value on the pupils as human beings, gives them confidence in their own experience where it conflicts with received wisdom, queries the models of knowledge and education underpinning the system, and encourages pupils to engage in positive change.

\section{Conclusions: Current Trends and Future Directions}

Recent years have seen some developments with significant implications for feminist pedagogy. Among these are Queer and Trans perspectives. Both Queer and Trans challenge feminism in the sense of further problematising the category of woman, albeit in very different ways. Queer casts doubt upon the adequacy of the view that sex is natural while gender is cultural (Butler 1999, p. 11) which is criticised for undermining the distinction between sex and gender by ignoring the sense of a stable identity and for appropriating Trans as evidence for its theory despite its antithetical premises (Hines 2006, pp. 50-51; Nash 2011, p. 197). Both have given rise to forms of religiosity and both have implications for the study of religions. Queer spirituality takes a multitude of forms such as the Sisters of Perpetual Indulgence (Glenn 2003, para. 40) and the Black Leather Wings of the Radical Faeries movement (Califa 2012, p. 98) while Trans spirituality has also emerged, including the worship of Kuan Yin who is portrayed as male where the female does not supersede but co-exists with the male (Bailey 2009, pp. 192-93). The contribution of Queer to the study of religion may be illustrated in relation to Butler's analysis of the complicity of religions are implicated in gender ideology, both to formulate hegemonic norms and facilitate their transgression (Deal and Beal 2004, p. 70). Similarly, 
the contribution of Trans to the study of religion includes highlighting the religious roles of Trans individuals in a variety of contexts (Bockting and Cesaretti 2001, pp. 292-93; Peletz 2006, pp. 310, 312). For feminist pedagogy in Religious Studies and Religious Education, Queer and Trans reinforce the requirement for inclusivity beyond the familiar concept of gender and the visibility of women within religions, raising wider issues about appropriate methods of research and supporting all learners and endorsing the value of empathy in the context of the equality and diversity agenda.

Queer and Trans perspectives also highlight that any concentration on one issue may mean that other and multiple forms of oppression are omitted. The insights of intersectionality turn on the failure of privileging/prioritising one identity category when inequality involves the intersection of such categories. As Crenshaw remarked, the failure to acknowledge the intersectional nature of oppression 'marginalizes those who are multiply-burdened and obscures claims that cannot be understood as resulting from discrete sources of discrimination' (Crenshaw 1989, p. 140). Thus, although political expediency may involve a narrow focus for a particular purpose, feminist pedagogy needs to make strategic alliances with other liberatory and progressive pedagogies in relation to issues of ethnicity, age, class, disability, sexuality, and of course religion which can also constitute the grounds for oppression.

Further, intersectionality casts a light on the debate about the educational under-achievement of boys and men that has attracted so much publicity since the 1990s, demonstrating that any concentration on gender alone may miss the factors actually operative in explaining differential achievement. Hence feminist pedagogy may be able to contribute to the formulation of appropriate educational policies and practices that avoid simplistic solutions structured around gender and offer a nuanced response to barriers to learning. In practice, feminist pedagogical strategies such as encouraging collaborative learning and articulating feelings and experience may prove helpful for boys and men in a way that is also of benefit for girls and women.

One way to conceptualise the nature and extent of progress in Religious Studies and Religious Education associated with or at least assisted by feminist pedagogy is to borrow the Jain doctrine of anekantavada, translated as 'non-onesidedness' (Long 2009, p. 117) or 'manypointedness' (Dundas 2002, p. 229). Arguably a form of perspectivism without relativism or scepticism, this doctrine stress that every statement is limited by its frame of reference and thus should be qualified appropriately, more popularly explained using the ancient Indian story of the blind men and the elephant. Each of the blind men describe what they experience of the elephant-trunk, leg, tail, flanks-but each has only a partial understanding, emphasising the need for multiple viewpoints. Applying this model to feminist pedagogy in Religious Studies and Religious Education, it can be applied to assess success in relation to content, methods and aims. In respect of content, whether the material reflects a variety of experiences, of women and not just or mainly men, lay adherents as much as religious specialists. In respect of methods, whether a variety of approaches are used, scholars and students are reflexive about their own contexts, and lived experience is examined alongside official teachings. In respect of aims, whether a balance is maintained between enabling students to succeed in the system as it is and emphasising a critique that embodies ethical and transformative aims for education.

In so doing, this model can also be inflected to take into account in feminist pedagogy the representation and agency of specific groups identified by ethnicity, age, class, disability, and sexuality as well as gender and religion where Religious Studies and Religious Education are shaped by various historical and contemporary factors related to diverse stakeholders. Looking at feminist pedagogy on this model demonstrates the complexity of a reality in which there are numerous overlapping patterns of advantage and disadvantage. Looking at Religious Studies and Religious Education on this model highlights a liberal Protestant culture, an imperial legacy, the existence of migrant communities and increasing secularisation. These are evident respectively: in the privileged position of the Church of England as the established church exemplified in the historical predominance of Theology over Religious Studies in universities and the statutory framework for Religious Education in schools; the prominence accorded Sikhism as a major religion in Religious Studies and Sikhism's 
inclusion among the so-called 'Big Six' world religions in Religious Education; the engagement of diasporic groups with the teaching of their faiths in both universities and schools; and the activism of organisations such as Humanists UK and the British Secular Society.

In conclusion, feminist pedagogy challenges Religious Studies and Religious Education to rethink their content, methods and aims in a variety of ways. These include, for example: scrutiny of the inherited body of subject knowledge for unexamined gender bias; inclusion of the experience of women as an integral, rather than supplementary, aspect of the curriculum; advocacy of an ethically-informed and engaged approach to the study of religions; establishment of collaborative relationships in a learning community that includes lecturers and teachers; affirmation of the centrality of students as individuals with their own talents and interests; and a vision of education that resists the reduction of education to preparation for employment when it should promote human flourishing in a holistic sense. Here, as with the feminist project in the round, there have been important advances in our lifetimes but there is much yet to achieve.

Author Contributions: Both authors worked collaboratively on this paper.

Conflicts of Interest: The authors declare no conflict of interest.

\section{References}

Alberts, Wanda. 2007. Integrative Religious Education in Europe: A Study of Religions Approach. Berlin: Walter de Gruyter, ISBN 798-3-11-019661-0.

Bailey, Cathryn. 2009. Embracing the Icon: The Feminist Potential of the Trans Bodhisattva, Kuan Yin. Hypatia 24: 178-19. [CrossRef]

BASR (British Association for the Study of Religion). n.d. The BASR Constitution. Available online: https: / / basr.ac.uk/constitution/ (accessed on 21 February 2018).

Baumfield, Vivienne. 2002. Thinking Through Religious Education. London: Chris Kington Publishing, ISBN 978-1899857463.

Bell, Diane. 2001. In the Tracks of the Munga-Munga. In Feminism in the Study of Religions: A Reader. Edited by Darlene. M. Juschka. London and New York: Continuum, pp. 252-82, ISBN 0-8264-4727-9.

Biesta, Gert. 2013. The Beautiful Risk of Education. Boulder: Paradigm, ISBN 978-1-61205-027-0.

Biesta, Gert. 2017. Education. Paper present at Religion and Education: The Forgotten Dimensions of Religious Education, Brunel University, London, UK, October 3.

Birkeland, Janis. 1993. Ecofeminism: Linking Theory and Practice. In Ecofeminism: Women, Animals, Nature. Edited by Greta Gaard. Philadelphia: Temple University Press, pp. 13-59, ISBN 978-143-990548-7.

Bockting, Walter O., and Charles Cesaretti. 2001. Spirituality, Transgender Identity, and Coming Out. Journal of Sex Education and Therapy 26: 291-300. [CrossRef]

Butler, Judith. 1999. Gender Trouble: Feminism and the Subversion of Identity, 2nd ed. London and New York: Routledge, ISBN 0-415-92499-5.

Califa, Patrick. 2012. Sadomasochism and Spirituality: A Queerly Religious Challenge to the Gay Marriage Paradigm. In Queer Religion Volume II LGBT Movements and Queering Religion. Edited by Donald. L. Boisvert and Jay Emerson Johnson. Santa Barbara, Denver and Oxford: Praeger, pp. 93-108, ISBN 978-0-313-35358-1.

Carr, Anne. 1990. Transforming Grace: Christian Tradition and Women's Experience. San Francisco: Harper and Row, ISBN 0-0625-4870-0.

Commission on Religious Education. 2017. Interim Report: Religious Education for All. London: RE Council, Available online: www.commissiononre.org.uk (accessed on 21 February 2018).

Conroy, James C., David Lundie, Robert A. Davis, Vivienne Baumfield, L. Philip Barnes, Tony Gallagher, Kevin Lowden, Nicole Bourque, and Karen Wenell. 2013. Does Religious Education Work? A Multi-Dimensional Investigation. London and New York: Bloomsbury, ISBN 978-1-4411-2799-0.

Crabtree, Robbin D., and David Alan Sapp. 2003. Theoretical, Political, and Pedagogical Challenges in the Feminist Classroom: Our Struggles to Walk the Walk. College Teaching 51: 131-40. [CrossRef] 
Crenshaw, Kimberle. 1989. Demarginalizing the Intersection of Race and Sex: A Black Feminist Critique of Antidiscrimination Doctrine, Feminist Theory and Antiracist Politics. University of Chicago Legal Forum 1989(1) Article 8. Available online: http:/ / chicago.unbound.uchicago.edu/uclf/vol1989/iss1/8 (accessed on 26 February 2018).

Cush, Denise. 2016. Combatting Sexism, Homophobia, Religionism, and Subjectism: Equality and Diversity in Religious Studies and Religious Education. In Diversity and Intersectionality: Studies in Religion, Education and Values. Edited by Jeff Astley and Leslie J. Francis. Bern: Peter Lang, pp. 153-70, ISBN 978-3-0343-2252-2.

Cush, Denise, and Catherine Robinson. 2014. Developments in Religious Studies: Towards a Dialogue with Religious Education. British Journal of Religious Education 36: 4-17. [CrossRef]

Cush, Denise, and Catherine Robinson. 2016. Brian Bocking and the Defence of Study of Religions as an Academic Discipline in Universities and Schools. Journal of the Irish Society for the Academic Study of Religions 3: 27-41. Available online: https:/ /jisasr.org/volume-3-2016 (accessed on 15 February 2018).

Deal, William E., and Timothy K. Beal. 2004. Theory for Religious Studies. New York and Abingdon: Routledge, ISBN 0-415-96638-8.

Dundas, Paul. 2002. The Jains, 2nd ed. London and New York: Routledge, ISBN 978-0-415-26606-2.

Farmer, David Hugh. 1988. The Oxford Dictionary of Saints, 2nd ed. Oxford and New York: Oxford University Press, ISBN 0-19282038-9.

Freathy, Giles, Robert Freathy, Jonathan Doney, Karen Walshe, and Geoff Teece. 2015. The RE-Searchers: A New Approach to Religious Education in Primary Schools. Exeter: University of Exeter, ISBN 978-0-9933713-1-8. Available online: http:/ / www.reonline.org.uk/re-searchers / (accessed on 15 February 2018).

Freire, Paulo. 1998. Pedagogy of Freedom: Ethics, Democracy, and Civic Courage. Lanham, Boulder, New York and London: Rowman and Littlefield, ISBN 0-8476-9046-6.

Gaard, Greta. 1993. Living Interconnections with Animals and Nature. In Ecofeminism: Women, Animals, Nature. Edited by Greta Gaard. Philadelphia: Temple University Press, pp. 1-12, ISBN 978-143-990548-7.

Glenn, Cathy B. 2003. Queering the (Sacred) Body Politic: Considering the Performative Cultural Politics of the Sisters of Perpetual Indulgence. Theory \& Event 7. [CrossRef]

Grimmitt, Michael. 2000. Pedagogies of Religious Education. Great Wakering: McCrimmons, ISBN 0-85597-621-7.

Grimmitt, Michael. 2010. Contributing to social and community cohesion. In Religious Education and Social and Community Cohesion. Edited by Michael Grimmitt. Great Wakering: McCrimmons, pp. 260-317, ISBN 978-0-85597-710-8.

Gross, Rita. 1996. Feminism and Religion: An Introduction. Boston: Beacon Press, ISBN 0-8070-6785-7.

Hines, Sally. 2006. What's the Difference? Bringing Particularity to Queer Studies of Transgender. Journal of Gender Studies 15: 49-66. [CrossRef]

Hooks, Bel. 1994. Teaching to Transgress: Education as the Practice of Freedom. New York and London: Routledge, ISBN 0-4159-0808-6.

Husbands, Chris, and Jo Pearce. 2012. What Makes Great Pedagogy? Nine Claims from Research. National College for School Leadership. Available online: https://www.gov.uk/government/uploads/system/uploads / attachment_data/file/329746/what-makes-great-pedagogy-nine-claims-from-research.pdf (accessed on 26 March 2018).

Isasi-Diaz, Ada Maria. 2001. Defining our Proyecto Historico: Mujerista strategies for liberation. In Feminism in the Study of Religions: A Reader. Edited by Darlene M. Juschka. London and New York: Continuum, pp. 498-509, ISBN 0-8264-4727-9.

Jakelic, Slavika, and Jessica Starling. 2006. Religious Studies: A Bibliographic Essay. Journal of the American Academy of Religion 74: 194-211. [CrossRef]

Jones, Constance A. 2002. Feminist Research in the Sociology of Religion. In Methodology in Religious Studies: The Interface with Women's Studies. Edited by Arvind Sharma. Albany: State University of New York Press, pp. 67-96, ISBN 0-7914-5348-0.

Jonte-Pace, Diane. 2002. The Impact of Women's Studies on the Psychology of Religion: Feminist Critique, Gender Analysis, and the Inclusion of Women. In Methodology in Religious Studies: The Interface with Women's Studies. Edited by Arvind Sharma. Albany: State University of New York Press, pp. 97-146, ISBN 0-7914-5348-0.

King, Ursula. 1990. Religion and Gender. In Turning Points in Religious Studies. Edited by Ursula King. London: T\&T Clarke, ISBN 978-0567095640. 
King, Ursula. 2002. Is There a Future for Religious Studies as We Know It? Some Postmodern, Feminist and Spiritual Challenges. Journal of the American Academy of Religion 70: 365-88. [CrossRef]

King, Ursula. 2010. Earthing Spiritual Literacy: How to Link Spiritual Development and Education to a New Earth Consciousness? Journal of Beliefs \& Values 31: 245-60. [CrossRef]

Kinsley, David. 2002. Women's Studies and the History of Religions. In Methodology in Religious Studies: The Interface with Women's Studies. Edited by Arvind Sharma. Albany: State University of New York Press, pp. 1-15, ISBN 0-7914-5348-0.

Kishimoto, Kyoko, and Mumbi Mwangi. 2009. Critiquing the Rhetoric of "Safety" in Feminist Pedagogy: Women of Color Offering an Account of Ourselves. Feminist Teacher 19: 87-102. [CrossRef]

Knott, Kim. 1995. Women Researching, Women Researched: Gender as an Issue in the Empirical Study of Religion. In Religion and Gender. Edited by Ursula King. Oxford and Cambridge: Blackwell, pp. 199-218, ISBN 0-631-19377-4.

Knott, Kim. 2017. The Study if Religion in the UK in its Institutional Context. Nederlands Theologisch Tikdschrift 71: 44-57, accepted. Available online: eprints.lancs.ac.uk/85904/04/1/Revised_Knott_NTT.pdf (accessed on 21 February 2018).

Long, Jeffery D. 2009. Jainism: An Introduction. London and New York: I.B. Tauris, ISBN 978-1-845-11626-2.

Madoc-Jones, Beryl. 1997. Women's Experience: Whose Knowledge Is It? In Into the Melting Point: Teaching Women's Studies in the New Millennium. Edited by Fiona Montgomery and Christine Collette. Aldershot and Brookfield: Ashgate, pp. 13-21, ISBN 1-85972-557-0.

Martin, Clarice J. 2001. Womanist Interpretations of the New Testament: The Quest for Holistic and Inclusive Translation and Interpretation. In Feminism in the Study of Religions: A Reader. Edited by Darlene M. Juschka. London and New York: Continuum, pp. 539-59, ISBN 0-8264-4727-9.

Mathieu, Nicole-Claude. 1996. Sexual, Sexed and Sex-Class Identities: Three Ways of Conceptualising the Relationship between Sex and Gender. In Sex in Question: French Materialist Feminism. Edited by Diana Leonard and Lisa Adkins. London and Bristol: Taylor and Francis, pp. 42-71, ISBN 0-7484-0294-2.

Montgomery, Fiona, and Christine Collette. 1997. Introduction. In Into the Melting Point: Teaching Women's Studies in the New Millennium. Edited by Fiona Montgomery and Christine Collette. Aldershot and Brookfield: Ashgate, pp. 1-12, ISBN 1-85972-557-0.

Nash, Catherine Jean. 2011. Trans Experiences in Lesbian and Queer Space. The Canadian Geographer 55: $192-207$. [CrossRef]

O'Connor, J. 1989. Rereading, Reconceiving and Reconstructing Feminist Research in Religion. Women's Studies 17: 101-23. [CrossRef]

O'Connor, June. 1995. The Epistemological Significance of Feminist Research in Religion. In Religion and Gender. Edited by Ursula King. Oxford and Cambridge: Blackwell, pp. 45-63, ISBN 0-631-19377-4.

Ofsted. 2013. Religious Education: Realising the Potential. Available online: http://www.Ofsted.gov.uk/ resources/religious-education-realising-potential (accessed on 19 February 2018).

Orr, Leslie C. 2000. Women's Wealth and Worship: Female Patronage of Hinduism, Jainism, and Buddhism in Medieval Tamilnadu. In Faces of the Feminine in Ancient, Medieval, and Modern India. Edited by Mandakranta Bose. New York and Oxford: Oxford University Press, pp. 124-47, ISBN 0-19-512229-1.

Peletz, Michael G. 2006. Transgenderism and Gender Pluralism in Southeast Asia since Early Modern Times. Current Anthropology 47: 309-40. [CrossRef]

Peskowitz, Miriam, Maria Pilar Aquino, Shelia Greeve Davaney, Nantawan B. Lewis, Emilie Maureen Townes, and Judith Plaskow. 2001. Roundtable Discussion: What's in a Name? Exploring the Dimensions of What "Feminist Studies in Religion" Means. In Feminism in the Study of Religions: A Reader. Edited by Darlene M. Juschka. London and New York: Continuum, pp. 386-410, ISBN 0-8264-4727-9.

Quality Assurance Agency for Higher Education. 2014. Subject Benchmark Statement: Theology and Religious Studies. Gloucester: Quality Assurance Agency for Higher Education, Available online: http://www. qaa.ac.uk/publications/information-and-guidance/publication?PubID=2833\#.WnhJ24LLhsY (accessed on 5 February 2018).

Rasing, Thera. 1995. Passing on the Rites of Passage. Amsterdam: African Studies Centre, ISBN 1-85972-301-2.

REC (Religious Education Council of England and Wales). 2013. A Review of Religious Education in England. Available online: http:/ / resubjectreview.recouncil.org.uk/re-review-report (accessed on 19 February 2018). 
Reid-Bowen, Paul. 2005. Reflexive Transformations: Research Comments on Me(n)Feminist Philosophy and the Thealogical Imagination. In Gender, Religion and Diversity: Cross-Cultural Perspectives. Edited by Ursula King and Tina Beattie. London and New York: Continuum, pp. 190-200, ISBN 0-8264-8845-5.

Russell, Amy Madalaine. 2011. Why Study Theology and Religious Studies. Available online: https://www. researchgate.net/publication/265634000 (accessed on 19 February 2018).

Schreiner, Peter. 2017. A European Perspective: How Educational Reforms Influence the Place and Image of RE. In We Need to Talk about Religious Education. Edited by Mike Castelli and Mark Chater. London and Philadelphia: Jessica Kingsley, pp. 37-51, ISBN 97-1-78592-269-5.

Shah, Sneh. 1997. Agenda for Women's Studies in the Context of Cultural Diversity Issues. In Into the Melting Point: Teaching Women's Studies in the New Millennium. Edited by Fiona Montgomery and Christine Collette. Aldershot and Brookfield: Ashgate, pp. 97-106, ISBN 1-85972-557-0.

Shaw, Rosalind. 1995. Feminist Anthropology and the Gendering of Religious Studies. In Religion and Gender. Edited by Ursula King. Oxford and Cambridge: Blackwell, pp. 65-76, ISBN 0-631-19377-4.

Smith, Wilfred Cantwell. 1978. The Meaning and End of Religion. London: SPCK, ISBN 0-2810-3576-8.

Smith, Jonathan Z. 1982. Imagining Religion: From Babylon to Jonestown. Chicago: University of Chicago Press, ISBN 9-7802-2676360-6.

Staal, Fritz. 1989. Rules without Meaning: Rituals, Mantras and the Human Sciences. New York: Peter Lang, ISBN 0-8204-0553-1.

Stenger, Mary Ann. 2002. Feminist Philosophy of Religion. In Methodology in Religious Studies: The Interface with Women's Studies. Edited by Arvind Sharma. Albany: State University of New York Press, pp. 147-78, ISBN 0-7914-5348-0.

TRS-UK. 2013. An Invitation to the Study of Religion: Why You should Think about a Degree in Religious Studies and Theology. Available online: trs.ac.uk/wp-content/uploads/2013/11/leaflet_high.pdf (accessed on 21 February 2018).

Warne, Randi R. 2000. Gender. In Guide to the Study of Religions. Edited by Willi Braun and Russell T. McCutcheon. London and New York: Cassell, pp. 140-54, ISBN 0-304-70176-9.

Welch, Penny. 1997. What Can Tutors and Students Do to Promote Egalitarian Relationships in the Women's Studies Classroom? In Into the Melting Point: Teaching Women's Studies in the New Millennium. Edited by Fiona Montgomery and Christine Collette. Aldershot and Brookfield: Ashgate, pp. 39-47, ISBN 1-85972-557-0.

Wiebe, Donald. 2005. Religious Studies. In The Routledge Companion to the Study of Religion. Edited by John R. Hinnells. Abingdon and New York: Routledge, pp. 98-124, ISBN 0-415-33311-3.

Young, Katherine K. 2002. From the Phenomenology of Religion to Feminism and Women's Studies. In Methodology in Religious Studies: The Interface with Women's Studies. Edited by Arvind Sharma. Albany: State University of New York Press, pp. 17-40, ISBN 0-7914-5348-0. 